 \\ $\mathbf{U F}$ \\ IFAS Extension
}

\section{Control of Redroot (Lachnanthes caroliniana) in Pastures ${ }^{1}$}

Jason Ferrell, Brent Sellers and Joseph Walter²

Redroot is a wetland plant that grows in environments ranging from shallow standing water to seasonally wet flatwoods soils. The most readily identifying features of this plant are the characteristic red rhizomes (Figure 1) and the flattened leaves (Figure 2).

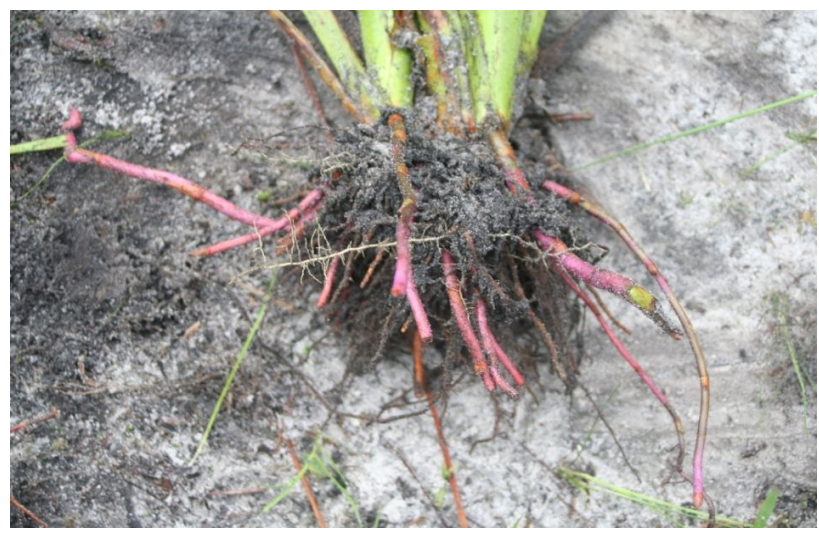

Figure 1. Red rhizomes of redroot.

Although redroot is not common in well established pastures, it can be problematic in newly established areas or those with open spots resulting from pasture decline or molecricket damage.

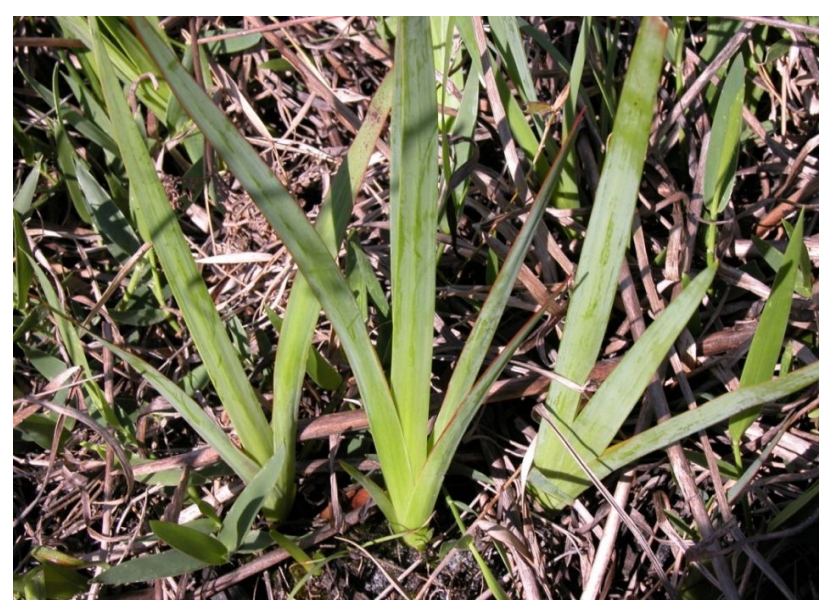

Figure 2. Flattened leaves of redroot. Credits: Jason Ferrell

Currently, no data exists for control of redroot in pastures.

Experiments were conducted in 2004 and 2006 to determine which herbicides were most effective for redroot control. It was observed that Weedmaster at 4 $\mathrm{pt} / \mathrm{A}$ was the most effective and consistent herbicide. Although Remedy at $2 \mathrm{pt} / \mathrm{A}$ provided acceptable control in 2006 it is more costly and likely not

1. This document is SS AGR 290, one of a series of the Agronomy Department, Florida Cooperative Extension Service, Institute of Food and Agricultural Sciences, University of Florida. Original publication date December 2007. Visit the EDIS Web Site at http://edis.ifas.ufl.edu.

2. Jason Ferrell, assistant professor, Agronomy Department; Brent Sellers, assistant professor, Range Cattle Research and Education Center--Ona, FL; J.

Walter, extension agent, Brevard County Extension Office; Florida Cooperative Extension Service, Institute of Food and Agricultural Sciences, University of Florida, Gainesville, FL 32611.

The use of trade names in this publication is solely for the purpose of providing specific information. UF/IFAS does not guarantee or warranty the products named, and references to them in this publication does not signify our approval to the exclusion of other products of suitable composition. All chemicals should be used in accordance with directions on the manufacturer's label.

The Institute of Food and Agricultural Sciences (IFAS) is an Equal Opportunity Institution authorized to provide research, educational information and other services only to individuals and institutions that function with non-discrimination with respect to race, creed, color, religion, age, disability, sex, sexual orientation, marital status, national origin, political opinions or affiliations. U.S. Department of Agriculture, Cooperative Extension Service, University of Florida, IFAS, Florida A. \& M. University Cooperative Extension Program, and Boards of County Commissioners Cooperating. Larry Arrington, Dean 
superior to Weedmaster alone. Velpar, Cimarron, and Roundup Weathermax were ineffective and should not be considered for control of redroot.

If redroot is growing in a newly established pasture, applications of Weedmaster should not be made to limpograss (Hemathria) at any time or to bahiagrass until it reaches an average height of 6 inches. Weedmaster can be injurious to small bahiagrass, but bahiagrass greater than 6 inches tall exhibits a high degree of tolerance. No more than 2 pt/A Weedmaster should be applied to bermudagrass or stargrass until 60 days after establishment.

Table 1.

\begin{tabular}{||l|c|c|c|c||}
\hline \hline Herbicide & Rate & 2004 & 2006 & Cost \\
\hline & Per acre & \multicolumn{2}{|c|}{$\%$ control } & $\$ / \mathrm{A}$ \\
\hline Cimarron & $1 \mathrm{oz}$ & 60 & 30 & 20 \\
\hline Velpar & $4.5 \mathrm{pt}$ & 50 & 30 & 31 \\
\hline Roundup Weathermax & $22 \mathrm{fl.} \mathrm{oz}$ & 40 & 40 & 9 \\
\hline Remedy & $2 \mathrm{pt}$ & 70 & 85 & 20 \\
\hline Plateau or Impose & $12 \mathrm{oz}$ & 50 & 70 & 24 \\
\hline Pasturegard & $3 \mathrm{pt}$ & 60 & - & 18 \\
\hline Weedmaster & $4 \mathrm{pt}$ & 85 & 85 & 16 \\
\hline \hline
\end{tabular}

